\title{
Physiological and biochemical characteristics of different tomato grown in Rajshahi region of Bangladesh
}

\author{
M. Ibrahim ${ }^{1 *}$, M. O. H. Helali ${ }^{1}$, A. K. M. S. Alam ${ }^{2}$, D. Talukder ${ }^{3}$ and S. Akhter ${ }^{4}$ \\ ${ }^{I}$ Fruits and Food Processing and Preservation Research Division, Bangladesh Council of Scientific and Industrial Research \\ Laboratories, Binodpur Bazar, Rajshahi, Bangladesh \\ ${ }^{2}$ Applied Botany Research Division, BCSIR Labs, Binodpur Bazar, Rajshahi, Bangladesh \\ ${ }^{3}$ Applied Zoology Research Division, BCSIR Labs, Binodpur Bazar, Rajshahi, Bangladesh \\ ${ }^{4}$ Institute of Biological Sciences, University of Rajahshi, Rajshahi, Bangladesh
}

\begin{abstract}
Physiological and biochemical characteristics of nine different tomato cultivars were studied in order to select the cultivar of overall best quality. The tomato cultivars (Lalima, Manik, Summer, Deshy, Anupama, Jhumka, Chaity, Bizly and Lovely) were collected from different places of Rajshahi region. Those cultivars showed variability in physiological and biochemical characteristics. The range for the tomato quality parameters are as follows: fruit weight (44.76-111.70g), juice (81.25-69.94\%), dry matter (7.58-9.92\%), moisture content (90.08-92.42\%), ash (0.438-0.530\%), acidity (0.083-0.129\% as citric acid), $\beta$-carotene (298-380 $\mathrm{g} / 100 \mathrm{~g})$, vitamin C (6.98-11.43 $\mathrm{mg} / 100 \mathrm{~g})$, total sugar $(3.45-4.52 \%)$, reducing sugar $(1.21-1.56 \%)$, non reducing sugar $(2.24-2.97 \%)$, protein $(0.525-0.654 \%)$, iron (0.152-0.215 mg/100g), phosphorous (21.94-28.31 mg/100g), calcium (38.15-42.31 mg/100g), carbohydrate (4.18-6.24\%), starch $(0.16-0.21 \%)$, and so on. Bizli tomato cultivar has the best overall qualities with respect to fruit colour, fruit size, fruit pulp taste. These data of quality characteristics of tomato provide important information for consumers, producers and industrial processor for plantation and processing industry.
\end{abstract}

Key words: Tomato cultivar; Physiological character; Biochemical composition; Quality; Adaptability and assessment

\section{Introduction}

The tomato (Lycopersicon esculentum Mill) fruit is one of the most popular, as well as important commodities in the world. It is one of the most important edible and nutritious vegetable crops in Bangladesh. It is a widely distributed annual vegetable crop, which is consumed fresh, cooked or after processing. It belongs to the family Solanaceae. It is cultivated in almost all home gardens and also in the field for its adaptability to wide range of soil and climate in Bangladesh. It ranks next to potato and sweet potato in respect of vegetable production in the world (Hossain et al., 2010). Over 20 million metric tons of tomato are produced every year on a world basis (Salunkhe et al., 1974). It is widely cultivated in tropical, sub-tropical and temperate climates and thus it ranks third in terms of world vegetable production. The leading tomato producing countries are China, USA, India, Egypt, Turkey, Iran, Mexico, Brazil and Indonesia (Hossain et al., 2010). In Bangladesh, tomato is cultivated all over the country due to its adaptability to wide range of soil and climate (Ahamad, 1995; Tiecher et al., 2013). It contains a number of nutritive elements almost double compared to fruit apple and shows superiority with regards to food values (Barman, 2007; Ajayi et al., 2009). Food value of tomato is great dependent on its chemical compositions such as dry matter, moisture, $\mathrm{pH}$, TSS, total sugar, reducing sugar, non reducing sugar, acidity, proteins, $\beta$-carotene, vitamin $\mathrm{C}$, starch, carbohydrate etc. Tomato flavour involves perception of the tastes and aroma of many chemical constituents. The flavour of a tomato is determined by the amount of sugar and acid present. Sugars, acids and their interactions are important for the sweetness, sourness and overall flavour intensity in tomatoes (De Bruyn et al., 1971; Stevens et al., 1977; Rai et al., 2011). High sugars and relatively high acids are required for the best flavour. High acids and low sugars will produce a tart tomato while high sugars and low acids will result in a bland taste, insipid tomato (Kader, 1986). Soluble solids content and titratable acidity, the main components responsible for tomato flavour (Kader, 1977; Mohamed and Ismail, 2011) are properties of the tomato most likely to match the consumer perception of the internal quality (Baldwin et al., 1998; Bravo et al., 2012). Tomato is a major vegetable crop for the tomato processing industry. High dry matter and soluble solids are desirable characteristics for the canned

\footnotetext{
*Corresponding author e-mail: dr.ibrahim62@yahoo.com
} 
tomato industry since they improve the quality of the processed product (Gould, 1983). Higher solid content in fruits is a target characteristic, as this would reduce cost of processing. Tomato fruit is $94-95 \%$ water and 5- 6\% organic compounds (solids) of which about $1 \%$ are skin and seeds. Dry matter content and the balance of the accumulation also determine percentage assimilates and water (Marschner, 1995). Hence, generally, soluble solids content measurements may give a fair estimate of the sugar level in tomato fruit. The sugars are mostly glucose and fructose and constitute about $65 \%$ of total soluble solids in expressed fruit juice (Gould, 1983). Awareness in respect of improved tomato production is lacking. In view of the above aspect, the present study has been undertaken to throw light on some of the constituents of tomato with a view of apprehending the fruit as a supplementary food having a good taste and calorific value as well as to select the varieties for plantation with a hope to be a member of tomato exporting countries.

\section{Materials and methods}

The experiment was carried out at Bangladesh Council of Scientific and Industrial Research Laboratories, Rajshahi, Bangladesh during the period from December 2015 to March 2016.The freshly harvested tomato fruits used in this experiment were procured from different areas in Rajshahi region and collected randomly from the garden with three replications. The physiological fruit characteristics of tomato viz. fruit size, fruit colour, pulp flavour, pulp taste, whole fruit weight and percentage of juice was done and recorded in Table I. The ripe tomatoes were cleaned, weighed and cut into pieces and juice was extracted. Moisture content was determined by oven drying method (Karmas, 1990), total soluble solids (TSS) was determined with a hand refractometer (Ranganna, 1986). Total sugar was determined by spectrophotometric method i.e. anthrone method (Dubois et al., 1956), reducing sugar was determined by spectrophotometric method i.e. DNS method (Miller, 1959), vitamin $\mathrm{C}$ was determined by spectrophotometric method using folin- phenol reagent (Jagota, 1982), acidity was determined by titrimetrically with the usual acid base titration method (Ranganna, 1986). The $\mathrm{pH}$ was determined with a digital pH meter (Ranganna, 1986), ash was determined by ashing method using muffle furnace (Mahadevan and Sridhar, 1982). $\beta$-carotene (Sathya et al., 2014), protein (Lowry et al., 1951), minerals i.e. calcium (Stern and Lewis, 1957), iron (Wong 1928), phosphorus (Fiske and Row, 1925), carbohydrate (Dubois et al., 1956) and starch (Dubois et al., 1956) all the parameters were determined by spectrophotometric method. All experiments were conducted at ambient temperature and carried out in three replications. The data were statistically analyzed and the mean of different parameters was compared by least significant difference (LSD). The organoleptic tests and the physiological fruit characters (i.e. colour, flavour, and taste) of these ripe tomatoes were carried out and evaluated by a panel of seven judges. The tomatoes were classified on the basis of their grading as excellent ( $80 \%$ or above), good (70-79\%) and fair (bellow 70\%) depending on colour, flavour and taste (DeBruyn et al., 1971; Kamis et al., 2004).

\section{Results and discussion}

The physiological fruit characters from Table I the fruit colour was found deep red only in deshi cultivar while manik, anupama and jhumka showed red colour and also lalima,

Table I. Physiological fruit characteristics of different ripe tomato cultivars grown in Rajshahi region of Bangladesh

\begin{tabular}{cccccccc}
\hline $\begin{array}{c}\text { Sl. } \\
\text { No. }\end{array}$ & $\begin{array}{c}\text { Name of } \\
\text { tomato } \\
\text { cultivars }\end{array}$ & Shape Size & Colour & Flavour & Taste & $\begin{array}{c}\text { Average } \\
\text { weight g }\end{array}$ & $\begin{array}{c}\text { Percentage of } \\
\text { juice }(\%)\end{array}$ \\
\hline 1. & Lalima & Oblong & Reddish & Weak & Light Sour & 111.70 & 80.00 \\
2. & Manik & Ellipsoid & Red & Medium & Sour & 84.88 & 76.25 \\
3. & Summer & Ellipsoid & Reddish & Weak & Light Sour & 57.54 & 78.75 \\
4. & Deshy & Oblate & Deep Red & Strong & Deep Sour & 87.32 & 80.08 \\
5. & Anupama & Oblate & Red & Weak & Light Sour & 71.80 & 81.25 \\
6. & Jhumka & Oblate & Red & Weak & Light Sour & 44.76 & 73.75 \\
7. & Chairy & Oblong & Reddish & Medium & Sour & 90.88 & 75.00 \\
8. & Bizly & Oblong & Reddish & Weak & Light Sour & 82.95 & 72.50 \\
9. & Lovely & Oblong & Reddish & Strong & Light Sour & 96.32 & 69.94 \\
\hline
\end{tabular}


summer, chaity and bizly showed reddish colour. Lalima, deshi , chaity, bizly and lovely produced oblong size of fruits whereas manik and summer are ellipsoid and also anupama and jhumka are oblate. The weak pulp flavour was observed in most of the cultivars but manik and chaity possess medium pulp flavour while deshi and lovely were of strong type (Kader et al., 1987).
The pulp of major cultivars were tasted light sour except manik and chaity which had sour and only deshi was deep sour taste. Significant $(\mathrm{p}<0.05)$ variation was observed among the different cultivars in respect of whole fruit weight. The maximum fruit weight was recorded in cultivar of lalima $(111.70 \mathrm{~g})$. The observed results are ingood agreement with the reported results of Hossain et al. (2010) who worked on tomato.

Table II. a. Biochemical fruit characteristics of different ripe tomato cultivars grown in Rajshahi region of Bangladesh

\begin{tabular}{|c|c|c|c|c|c|c|c|c|c|}
\hline S1. No. & $\begin{array}{c}\text { Name of } \\
\text { tomato } \\
\text { cultivars }\end{array}$ & $\begin{array}{c}\text { Moisture } \\
(\%)\end{array}$ & Dry matter & $\begin{array}{c}\text { Total } \\
\text { soluble } \\
\text { solids } \\
(\%)\end{array}$ & $\mathrm{pH}$ & $\begin{array}{l}\text { Ash } \\
(\%)\end{array}$ & $\begin{array}{c}\text { Acidity } \\
(\%) \text { as } \\
\text { citric } \\
\text { acid }\end{array}$ & $\begin{array}{c}\beta \text {-carotene } \\
\mu \mathrm{g} / 100 \mathrm{~g}\end{array}$ & $\begin{array}{c}\text { Vitamin } \\
\mathrm{C} \\
\mathrm{mg} / 100 \mathrm{~g}\end{array}$ \\
\hline 1. & Lalima & 92.34 & 7.66 & 5.3 & 4.48 & 0.461 & 0.126 & 347.43 & 09.23 \\
\hline 2. & Manik & 90.87 & 9.13 & 5.8 & 4.35 & 0.438 & 0.093 & 329.27 & 10.15 \\
\hline 3. & Summer & 91.32 & 8.68 & 5.5 & 4.38 & 0.512 & 0.083 & 323.36 & 10.38 \\
\hline 4. & Deshy & 91.65 & 8.35 & 4.7 & 5.05 & 0.527 & 0.096 & 341.26 & 11.02 \\
\hline 5. & Anupama & 92.42 & 7.58 & 4.8 & 5.15 & 0.530 & 0.129 & 363.47 & 11.43 \\
\hline 6. & Jhumka & 92.08 & 9.92 & 5.6 & 4.70 & 0.518 & 0.108 & 317.58 & 06.98 \\
\hline 7. & Chaity & 90.68 & 9.32 & 6.2 & 4.55 & 0.462 & 0.131 & 298.25 & 10.36 \\
\hline 8. & Bizly & 91.65 & 8.35 & 7.5 & 4.48 & 0.485 & 0.145 & 380.42 & 11.09 \\
\hline 9. & Lovely & 92.08 & 7.92 & 6.5 & 4.60 & 0.488 & 0.108 & 351.35 & 10.83 \\
\hline \multicolumn{2}{|c|}{ LSD at $5 \%$ level } & 0.0485 & 0.0314 & 0.0327 & 0.0128 & 0.00063 & 0.00051 & 0.7328 & 0.0418 \\
\hline \multicolumn{2}{|c|}{ LSD at $1 \%$ level } & 0.0526 & 0.0412 & 0.0582 & 0.0203 & 0.00098 & 0.00072 & 0.9647 & 0.0535 \\
\hline
\end{tabular}

Table II. b. Biochemical fruit characteristics of different ripe tomato cultivars grown in Rajshahi region of Bangladesh

\begin{tabular}{lcccccccccc}
\hline S1. No. & $\begin{array}{c}\text { Name of } \\
\text { tomato } \\
\text { cultivars }\end{array}$ & $\begin{array}{c}\text { Total } \\
\text { sugar } \\
(\%)\end{array}$ & $\begin{array}{c}\text { Reducing } \\
\text { sugar } \\
(\%)\end{array}$ & $\begin{array}{c}\text { reducing } \\
\text { sugar } \\
(\%)\end{array}$ & $\begin{array}{c}\text { Protein } \\
(\%)\end{array}$ & $\begin{array}{c}\text { Iron } \\
\mathrm{mg} / 100 \mathrm{~g}\end{array}$ & $\begin{array}{c}\text { Phospho- } \\
\text { rous } \\
\mathrm{mg} / \\
100 \mathrm{~g}\end{array}$ & $\begin{array}{c}\text { Calcium } \\
\mathrm{mg} / 100 \mathrm{~g}\end{array}$ & $\begin{array}{c}\text { Carbo- } \\
\text { hydrate } \\
(\%)\end{array}$ & $\begin{array}{c}\text { Starch } \\
(\%)\end{array}$ \\
\hline 1. & Lalima & 3.45 & 1.21 & 2.24 & 0.612 & 0.163 & 26.50 & 38.15 & 4.18 & 0.18 \\
2. & Manik & 4.20 & 1.37 & 2.83 & 0.583 & 0.148 & 28.21 & 40.53 & 4.35 & 0.16 \\
3. & Summer & 3.85 & 1.32 & 2.53 & 0.525 & 0.154 & 22.48 & 41.37 & 5.08 & 0.21 \\
4. & Deshy & 3.62 & 1.28 & 2.34 & 0.631 & 0.152 & 22.94 & 42.31 & 5.13 & 0.17 \\
5. & Anupama & 3.57 & 1.25 & 2.32 & 0.625 & 0.178 & 28.31 & 40.93 & 4.65 & 0.19 \\
6. & Jhumka & 3.83 & 1.31 & 2.52 & 0.654 & 0.215 & 27.53 & 40.65 & 5.21 & 0.16 \\
7. & Chaity & 4.13 & 1.40 & 2.73 & 0.575 & 0.203 & 21.94 & 41.21 & 5.58 & 0.18 \\
8. & Bizly & 4.52 & 1.55 & 2.97 & 0.538 & 0.213 & 23.96 & 40.57 & 6.21 & 0.22 \\
9. & Lovely & 3.96 & 1.28 & 2.68 & 0.552 & 0.196 & 24.27 & 41.23 & 6.24 & 0.19 \\
LSD at 5\% level & 0.0318 & 0.0127 & 0.0216 & 0.00065 & 0.00043 & 0.0382 & 0.0413 & 0.0352 & 0.00033 \\
\multicolumn{2}{l}{ LSD at $1 \%$ level } & 0.0421 & 0.0216 & 0.0374 & 0.00082 & 0.00057 & 0.0493 & 0.0527 & 0.0475 & 0.00048 \\
\hline
\end{tabular}


Table III. Grading of ripe tomato as judged by the panel of seven judges based on general qualities of tomatoes

\begin{tabular}{|c|c|c|c|c|c|c|c|c|c|c|c|c|}
\hline \multirow{2}{*}{$\begin{array}{l}\text { Sl. } \\
\text { No. }\end{array}$} & \multirow{2}{*}{$\begin{array}{l}\text { Name of } \\
\text { tomato } \\
\text { cultivars }\end{array}$} & \multirow{2}{*}{$\begin{array}{l}\text { Physical } \\
\text { characters }\end{array}$} & \multicolumn{7}{|c|}{ Marking by Individual Judges } & \multirow[t]{2}{*}{ Total } & \multirow[t]{2}{*}{ Mean } & \multirow{2}{*}{$\begin{array}{l}\text { Order of } \\
\text { rating }\end{array}$} \\
\hline & & & 1 & 2 & 3 & 4 & 5 & 6 & 7 & & & \\
\hline \multirow[t]{3}{*}{1.} & \multirow{3}{*}{ Lalima } & Colour & 70 & 65 & 68 & 75 & 72 & 71 & 69 & 490 & 70.0 & Good \\
\hline & & Flavour & 63 & 58 & 57 & 67 & 53 & 59 & 64 & 521 & 60.1 & Fair \\
\hline & & Taste & 81 & 83 & 85 & 84 & 82 & 80 & 82 & 577 & 82.4 & Excellent \\
\hline \multirow[t]{3}{*}{2.} & \multirow{3}{*}{ Manik } & Colour & 60 & 52 & 57 & 49 & 50 & 52 & 48 & 368 & 52.6 & Fair \\
\hline & & Flavour & 45 & 43 & 41 & 50 & 53 & 51 & 49 & 332 & 47.4 & Fair \\
\hline & & Taste & 63 & 61 & 58 & 45 & 61 & 56 & 45 & 389 & 55.6 & Fair \\
\hline \multirow[t]{3}{*}{3.} & \multirow{3}{*}{ Summer } & Colour & 73 & 78 & 69 & 73 & 75 & 71 & 76 & 515 & 73.6 & Good \\
\hline & & Flavour & 93 & 74 & 88 & 71 & 74 & 98 & 96 & 614 & 87.7 & Excellent \\
\hline & & Taste & 90 & 93 & 89 & 94 & 96 & 84 & 87 & 633 & 90.4 & Excellent \\
\hline \multirow[t]{3}{*}{4.} & \multirow{3}{*}{ Deshy } & Colour & 72 & 78 & 73 & 80 & 84 & 70 & 74 & 531 & 75.9 & Good \\
\hline & & Flavour & 66 & 72 & 65 & 63 & 68 & 81 & 62 & 477 & 68.1 & Fair \\
\hline & & Taste & 74 & 73 & 79 & 82 & 85 & 80 & 76 & 549 & 78.4 & Good \\
\hline \multirow[t]{3}{*}{5.} & \multirow{3}{*}{ Anupama } & Colour & 75 & 72 & 78 & 63 & 86 & 79 & 77 & 520 & 74.3 & Good \\
\hline & & Flavour & 72 & 83 & 70 & 75 & 78 & 80 & 81 & 539 & 77.0 & Good \\
\hline & & Taste & 90 & 86 & 95 & 79 & 88 & 87 & 82 & 607 & 86.7 & Excellent \\
\hline \multirow[t]{3}{*}{6.} & \multirow{3}{*}{ Jhumka } & Colour & 67 & 77 & 65 & 72 & 78 & 71 & 62 & 492 & 70.3 & Good \\
\hline & & Flavour & 60 & 57 & 54 & 63 & 65 & 60 & 59 & 418 & 59.7 & Fair \\
\hline & & Taste & 73 & 68 & 74 & 77 & 69 & 65 & 72 & 498 & 71.1 & Good \\
\hline \multirow[t]{3}{*}{7.} & \multirow{3}{*}{ Chaity } & Colour & 65 & 71 & 60 & 74 & 66 & 75 & 68 & 479 & 68.4 & Fair \\
\hline & & Flavour & 63 & 60 & 68 & 72 & 65 & 76 & 70 & 474 & 67.7 & Fair \\
\hline & & Taste & 70 & 73 & 61 & 66 & 74 & 70 & 62 & 476 & 68.0 & Fair \\
\hline \multirow[t]{3}{*}{8.} & \multirow{3}{*}{ Bizly } & Colour & 92 & 90 & 88 & 87 & 93 & 94 & 87 & 631 & 90.1 & Excellent \\
\hline & & Flavour & 75 & 82 & 80 & 85 & 78 & 76 & 84 & 560 & 80.0 & Excellent \\
\hline & & Taste & 78 & 88 & 78 & 86 & 88 & 86 & 83 & 587 & 83.9 & Excellent \\
\hline \multirow[t]{3}{*}{9.} & \multirow{3}{*}{ Lovely } & Colour & 82 & 76 & 72 & 80 & 84 & 82 & 79 & 555 & 74.3 & Good \\
\hline & & Flavour & 78 & 72 & 88 & 73 & 78 & 82 & 81 & 532 & 76.0 & Good \\
\hline & & Taste & 80 & 85 & 81 & 78 & 85 & 82 & 80 & 571 & 81.6 & Excellent \\
\hline
\end{tabular}

The biochemical fruit characters i.e. moisture content, dry matter, TSS, $\mathrm{pH}$, ash, acidity, $\beta$-carotene, vitamin $\mathrm{C}$, total sugar, reducing sugar, non reducing sugar, protein, iron, phosphorus, calcium, carbohydrate, starch of different tomato cultivars varied among the cultivars and presented in Table IIa. and Table IIb. and wide variation was observed in all the parameters. Maximum moisture content $(92.42 \%)$ was found in cultivar anupama while minimum dry matter $(7.58 \%)$ was found in same cultivar. Total soluble solids (TSS) and $\mathrm{pH}$ were ranged from (4.7 to $7.5 \%)$ and (4.38 to 5.15$)$ respectively. The highest acidity $(0.145 \%$ as citric) was observed in cultivar of chaity followed by jhumka and lalima whereas summer cultivar had the lowest acidity $(0.083 \%$ as citric acid). Ash contained in different tomato cultivars ranged from 0.438 to $0.530 \%$ and $\beta$-carotene and vitamin $C$ were ranged from 298 to $380 \mu \mathrm{g} / 100 \mathrm{~g}$ and 6.98 to $11.43 \mathrm{mg} / 100 \mathrm{~g}$. Total sugar content was found the highest $(4.52 \%)$ in bizly cultivar whereas the lowest $(3.45 \%)$ found in the cultivar of 
lalima. Maximum reducing sugar content is $1.55 \%$ and maximum non reducing sugar content $(2.97 \%)$ was found in the cultivar of bizly. Protein, carbohydrate and starch were ranged from $(0.525-0.654 \%),(4.18-6.24 \%)$ and $0.16-0.21 \%$ respectively. Minerals commonly found in tomato fruits and have buffering capacity as well, therefore they influence the taste of tomatoes. Iron, phosphorous and calcium ranged from $(0.152-0.215 \mathrm{mg} / 100 \mathrm{~g}), \quad(21.94-28.31 \mathrm{mg} / 100 \mathrm{~g})$ and (38.15-42.31 mg/100g) respectively. Consumer's acceptability of tomato depends mainly on appearance, colour, flavour and taste. Hence, organoleptic test were done on pulp (flesh) colour, flavour and taste of these fruit by a panel of seven judges. Kader et al., (1978) also conducted similar study on tomatoes taking the parameter of pulp colour, flavour, taste and texture. Table III shows that the results of the preferential comments from the panel members were summarized and converted into acceptability scores and also order of rating (Bruhn et al., 1991).

In this study, the cultivar bizly (excellent) rank the highest in the total acceptability followed by the cultivar of manik, chaity, summer and jhumka (Baldwin et al., 1998, DeBruyn et al., 1971 and Ereifej et al., 1997). The results showed that there are significant variation in the physiological fruit characters and biochemical composition of tomato such as pulp colour, flovour, taste, whole weight, percentage of juice, TSS, $\mathrm{pH}$, acidity, $\beta$-carotene, vitamin $\mathrm{C}$, sugar, reducing sugar, non reducing sugar, protein, starch, moisture content, carbohydrate and minerals. The study provides important information to the processing industry to produce better quality of product and to inform the growers that which tomato cultivar has a potential market for commercial cultivation.

\section{Conclusion}

The results shown in this paper conveys that the tomato cultivars play an important role on human nutrition and nullify the harmful effect of trace metabolic impurities and also industrial utilization. This study provides important information to the processing industry to produce better quality of product and to inform the growers that tomato has a potential market for commercial cultivation. Among these, bizly cultivar of tomato is best for cultivation and consumption.

\section{Acknowledgement}

The authors are grateful to the Director, Bangladesh Council of Scientific and Industrial Research (BCSIR) Laboratories, Rajshahi for providing necessary laboratory facilities to carry out the research work. The authors are indebted to Mr. Md. Ziaullah Shafique, Chief Scientific Officer (Retd.), BCSIR Laboratories, Rajshahi for his heartiest co-operation to analyse the data and valuable suggestions. Authors are also grateful to the Ministry of Science and Technology, People's Republic of Bangladesh for approval of special allocation project and financial support.

\section{References}

Ahamad K (1995), Pul Phal O Shak-Sabjee, 5 ${ }^{\text {th }}$ Ed., 44 Senpara, Mirpur, Dhaka, p 440.

Ajayi AA, and Olasehinde IG (2009), Studies on the $\mathrm{pH}$ and protein content of tomato (Lycopersicon escolentum Mill.) fruits deteriorated by Aspergillus niger, Scientific Research and Essay 4(3): 185-187.

Barman SC (2007), Real adoption impact measure of tomato technologies on production at farmer's level in Bangladesh, Bangladesh J. Sci. Ind. Res. 42(1): 15-28.

Baldwin EA, Scott JW, Einstein MA, Malundo TMM, Carr BT, Shewfelt RL and Tandon KS (1998), Relationship between sensory and instrumental analysis for tomato flavor, J. Am, Soc. Hort. Sci. 123: 906-915.

Bravo S, Garcia-Alonso J, Martin-Pozuelo G, Gomez V, Santaella M and Navarro-Gonzalez I (2012), The influence of postharvest UV-C hormesis no lycopen, $\beta$-carotene and phenolic content antioxidant activity of breaker tomato, Food Research International 49: 296-302.

Bruhn CM, Feldman N, Garlitz C, Harwood J, lvans E, Marshall M, Riley A, Thurber D and Willamson E (1991), Consumer perceptions of quality : apricots, cantaloupes, peaches, pears, strawberries and tomatoes, J. Food Qual. 14: 187-195.

DeBruyn J, Garretsen F and Kooistra E (1971), Variation in taste and chemical composition of the tomato, Euphytica 20: 214-227.

Dubois M, Gilles KA, Hamilton JK, Rebers PA and Smith F (1956), A colorimetric method for determination of sugar, Anal. Chem. 28(3): 360-366.

Ereifej Kl, Shibli RA, Ajlouni MM and Hussain A (1997), Physico-chemical characteristics and processing quality of newly introduced seven tomato cultivars in to Jordan in comparison with local variety, J. Food Sci. and Tech. Mysore 34(2): 171-174. 
Fisk CH and Row YS (1925), The colorimetric determination of phosphorus, J. Biol. Chem. 66: 375-400.

Gould Wa (1983), Tomato Production, Processing and Quality Evaluation, AVI Publishing Co., Westport, p 445.

Hossain, ME, Alam MJ, Hakim MA, Amanullah ASM and Ahsanullah ASM (2010), An assesment of physico chemical properties of some tomato genotypes and varieties grown at Rangpur, Bangladesh Res. Pub.J. 4(3): 135-243.

Jagota SK and Dani HM (1982), A new Colorimetric technique for the estimation of vitamin $\mathrm{C}$ using Foloin-Phenol reagent, Anal. Biochem 127: 178-182.

Kader AA, Stevens MA, Albright-Holton M, Morris LL and Agazi M (1977), Effect of Fruit ripeness when picked on flavor and composition in fresh market tomatoes, $J$. Am. Soc. Hort. Sci. 102: 724-731.

.Kader AA (1986), Effect of post harvest handling procedures on tomato quality, Acta Hort. 190: 209-221.

Kader AA, Moris LL, Stevens MA and Albright-Holton M (1978), Composition and flavor quality of fresh market tomatoes as influenced by some post harvest handling, J. Am. Soc. Hort. Sci. 103(1): 6-11.

Kamis AB, Modu AS, Bobbai and Mwajim B (2004), Effect of ripening of the proximate and some biochemical composition of a local tomato cultivar grown at Lake Alau region of Borno State, J. App. Sci. 4(3): 424-426.

Karmas E (1990), Techniques for measurement of moisture content of foods, Food Technology 34: 52.

Lowry OH, Rosebrough NJ, Farr AL and Randall RJ (1951), Protein measurement with the Folin-Phenol reagent, $J$. Biol. Chem. 193: 265-275

Mahadevan A and Sridhar R (1982), Methods in Physiological Plant Pathology, Sivakami Publications, Indira Nagar, Madras 600020, India, p 171.

Marschner H (1995), Mineral nutrition of higher plant, Ann. Bot. 78: 523-528.

Miller G L (1959), Use of dinitrosalicylic acid reagent for determination of reducing sugar, Anal. Chcm. 31(3): 426-428.
Mohmed AN and Ismail MR (2011), Changes in inorganic and organic solutes of in vitro tomato cultivars under $\mathrm{NaCl}$ stress, Australian Journal of Crop Science 5(8): 939-944.

Ranganna S (1986), Handbook of Analysis and Quality Control for Fruit \& Vegetable Products, Tata Mc Graw- Hill Publishing Company Ltd., New Delhi, pp 1101.

Rai GK, Kumar R, Singh J, Rai PK and Rai SK (2011), Peroxidase, polyphenol oxidase activity, protein profile and phenolic content in tomato cultivars tolerant susceptible to Fusarium oxiporum F. sp. Lycopersici, Pakistan Journal of Botany 43(6): 2987-2990.

Salunkhe DK, Jadhav SJ and Yu MH (1974), Quality and nutritional composition of tomato fruit as influenced by certain biochemical and physiological changes, Qual. Plant-Pl. Fds.hum. Nutr. XXIV 1/2: 85-113.

Stevens MA, Kader AA, Albright-Holton M and Algazi M (1977), Genotypic variation for flavor and composition in fresh tomatoes, J. Am. Soc. Hot. Sci. 102: 880-689.

Sathya M, Sumathi P and John Joel A (2014), A simple and rapid screening technique for grain $\beta$-carotene content in pearl millet through spectrophotometric method, African J. Agril.Res. 9(5): pp.572-576.

Stern J and Lewis WHP (1957), The colorimetric estimation of calcium in serum with O-cresolphthalein complexon, Clinica Chimica Acta. 2(6): 576-580.

Tiecher A, De Paula LA, Chaves FC and Rambaldi CV (2013), UV-C effect on ethylene, polyamines and the regulation of tomato fruit ripening, Postharvest Biol. Technol. 86: 230-239.

Wong SY (1928), Colorimetric determination of iron and hemoglobin in blood, J. Biol. Chem. 77: 409-412.

Received: 20 November 2016; Revised: 15 December 2016; Accepted: 28 December 2016. 